\title{
Management of Root-Knot Disease in Phaseolus vulgaris Using Potassium Fertilizer and Biocontrol Agents
}

\author{
Rushda Sharf*, Hisamuddin, Abbasi and Ambreen Akhtar \\ Department of Botany, Aligarh Muslim University, Aligarh-202002, India
}

\begin{abstract}
The experiment was conducted to determine the effect of different doses of potassium fertilizer $\left(\mathrm{K}_{2} \mathrm{O}\right)$ along with the biofertilizers, Trichoderma harzianum, and Pochonia chlamydosporia, in the management of the root-knot disease caused by the root-knot nematode (Meloidogyne incognita) and on the growth and physiological parameters of Phaseolus vulgaris. From the result it was observed that the application of potassium along with biofertilizers in the treatment T-7 in which plants were treated with double dose of potassium along with both fungal biocontrol agents and root-knot nematode, improved all the growth as well as biochemical parameters viz, chlorophyll, protein, nitrate reductase, nitrogen and phosphorus contents and reduced the number of galls per root system in comparison to the control and other treatments.
\end{abstract}

Keywords: Phaseolus vulgaris; Potassium oxide; Root-knot Nematode; Trichoderma harzianum; Pochonia chlamydosporia; Meloidogyne incognita

\section{Introduction}

The red kidney bean (Phaseolus vulgaris) is one of the most important leguminous plants worldwide and is the highly relished pulse grain in Northern India. The bean seeds contain an important source of dietary protein amounting to $22 \%$ of the total seed weight. The root-knot nematode causes great damage, to more than 300 plant species [1], and is one of the devastating pathogen of the common bean in temperate and tropical regions $[2,3]$.

The nematode infection directly or indirectly affects the plant host physiology and total yield by changing the elemental concentration, (Melakeberhan et al.,) [4] resulting in changes in nutritional value of the crop. Therefore, it is necessary to control this nematode in order to reduce the crop losses. Several chemical pesticides and nematicide are being used for controlling the nematodes, but now a day's management by chemicals methods is not recommended because of risk of human being and the environment. Besides this, the biological control agents are used to control plant pathogens as alternative control strategies such as potassium nutrition and /or biocontrol agents are needed. Several fungal antagonists against the plant parasitic nematodes have been identified and applied [5-7]. Trichoderma sp. widely used for nematode control can survive in the soil in the presence of compost around the rhizosphere, and has a high nematicidal property against the nematode [8]. Direct parasitism of egg and larva through the increase in chitinase and protease activities and inducing plant defense response are the two mechanism of action of Trichoderma spp. which are thought to be responsible for controlling nematode. Biocontrol activity of Trichoderma sp against the $M$. incoginta in soil has been reported by Sharon et al., [9]. Trichoderma can promote the plant growth, increase phosphate solubility and availability of micronutrients in the soil [10]. Pochonia chlamydosporia is another nematophagous biological control agent, which can infect the nematode eggs, larvae and ingest adult, and is used for egg parasitism of Meloidogyne sp [11]. It acts as true endophyte, colonizing the plant root of many crops such as tomato and barley $[12,13]$. Endophytic colonization by $P$. chlamydosporia provides the protection of host plant against different soil pathogen such as nematode and fungi, also promote the plant growth by facilitating the soil nutrient uptake $[14,15]$.
In plant disease management use of commercial fertilizers in combination with biofertilizers can be implemented. Melakebarhan, et al. [4] reported significant decrease in the photosynthetic rate and crop yield with increasing nematode inoculums level and duration of infection, in the bean plant infected with Meloidogyne incognita. The disease was associated with leaf chlorosis, premature abscission and with changes in the nutrient elemental concentration [16]. Potassium an essential element for plant nutrition affect the plant growth and crop production by making plant resistant to disease, producing hard and strong stem, reduces lodging, increases performance and transfer of starch, sugar and fat and make the plant resistant to the frost [17]. It also plays an important role in host/pathogen relationship as defense mechanism [18]. Application of potassium increases the plant resistance by increasing the epidermal cell wall thickness and increase the plant growth [19]. Gupta and Mukhopadhayaya [20] reported that increase level of potassium have significantly reduced the number of galls of M. javanica in tomato.

The objective of this work was to study the effect of different doses of potassium in combination with biofertilizers (Trichoderma harzianum, and Pochonia chlamydosporia) on the growth of plant infected with root-knot nematode.

\section{Material and Methods}

The root-knot nematode, Meloidogyne incognita was selected as the test pathogen; Trichoderma harzianum and Pochonia chlamydosporia as the test biocontrol agents, which were added into the soil together with the potassium fertilizers for the control of root-knot nematode on kidney bean, Phaseolus vulgaris the experiment was performed in glass house.

*Corresponding author: Rushda Sharf, Department of Botany, Aligarh Muslim University, Aligarh-202002, India, Tel: 0571270 0935; E-mail: rush.khan09@gmail.com

Received: November 10, 2014; Accepted November 24, 2014; Published November 28, 2014

Citation: Sharf R, Hisamuddin, Abbasi, Akhtar A (2014) Management of Root-Knot Disease in Phaseolus vulgaris Using Potassium Fertilizer and Biocontrol Agents. J Plant Pathol Microb 5: 242. doi:10.4172/2157-7471.1000242

Copyright: @ 2014 Sharf $\mathrm{R}$, et al. This is an open-access article distributed under the terms of the Creative Commons Attribution License, which permits unrestricted use, distribution, and reproduction in any medium, provided the original author and source are credited. 


\section{Culturing of nematode}

Pure culture of Meloidogyne incognita from single egg mass was maintained on brinjal plants (Solanum melongena) in the green house for obtaining sufficient number of second-stage juveniles.

\section{Nematode inoculum}

For obtaining second-stage juveniles of the nematode, Meloidogyne incognita infected brinjal plants were uprooted and washed gently under tap water. The egg masses were carefully removed from galled roots and placed in $10 \mathrm{~cm}$ diameter, 15 mesh coarse sieves in which crossed layers of tissue papers were placed. The sieves were kept in petridishes containing sufficient water with lower part partially submerged in water. The petridishes were covered and kept in an incubator at $25^{\circ} \mathrm{C}$. After $24 \mathrm{~h}$ onwards second-stage juveniles were collected and stored for later use, and fresh water was added. The number of juveniles was counted using counting dish.

\section{Culture of fungus}

Pure cultures of both the fungi T. harzianum and P. chlamydosporia were obtained from IARI, New Delhi. These were grown and maintained on the Richards medium at $25 \pm 1^{\circ} \mathrm{C} .10 \mathrm{ml}$ of suspension contained one g of mycelium [21].

Potassium fertilizer, potassium oxide $\left(\mathrm{K}_{2} \mathrm{O}\right)$ was used as a fertilizer where $\mathrm{K} 1, \mathrm{~K} 2$ and $\mathrm{K} 3$ doses were evaluated at 50, 100 and $150 \mathrm{mg} /$ pot.

\section{Maintenance of Test Plant}

The seeds of Phaseolus vulgaris procured from the Indian Institute of Pulse Research (IIPR), Kanpur were sterilized by treating with $1 \%$ sodium hypochlorite $(\mathrm{NaOCl})$, and sown in $30 \mathrm{~cm}$ earthen pots filled with autoclaved soil having mixed compost. After one week of emergence of seedlings thinning was done to retain only one seedling per pot. Each pot was given treatment differently,

$$
\mathrm{C}=\text { control, } \mathrm{T} 1=1,000 \mathrm{~J}_{2} \text {, }
$$

$\mathrm{T} 2=\mathrm{K} 1+\mathrm{Th}(80 \mathrm{ml})+1,000 \mathrm{~J}_{2}, \mathrm{~T} 3=\mathrm{K} 1+\mathrm{Pc}(80 \mathrm{ml})+1,000 \mathrm{~J}_{2}$, $\mathrm{T} 4=\mathrm{K} 1+\mathrm{Th}(80 \mathrm{ml})+\mathrm{Pc}(80 \mathrm{ml})+1,000 \mathrm{~J}_{2}, \mathrm{~T} 5=\mathrm{K} 2+\mathrm{Th}(80 \mathrm{ml})+1,000$ $\mathrm{J}_{2}, \mathrm{~T} 6=\mathrm{K} 2+\mathrm{pc}(80 \mathrm{ml})+1,000 \mathrm{~J}_{2}, \mathrm{~T} 7=\mathrm{K} 2+\mathrm{Th}(80 \mathrm{ml})+\mathrm{Pc}(80 \mathrm{ml})+$ $1,000 \mathrm{~J}_{2}, \mathrm{~T} 8=\mathrm{K} 3+\mathrm{Th}(80 \mathrm{ml})+1,000 \mathrm{~J}_{2} \mathrm{~T} 9=\mathrm{K} 3+\mathrm{pc}(80 \mathrm{ml})+1,000 \mathrm{~J}_{2}$ $\mathrm{T} 10=\mathrm{K} 3+\mathrm{Th}(80 \mathrm{ml})+\mathrm{Pc}(80 \mathrm{ml})+1,000 \mathrm{~J}_{2}$,

$\mathrm{K} 1=50 \mathrm{mg} /$ pot, $\mathrm{K} 2=100 \mathrm{mg} /$ pot, $\mathrm{K} 3=150 \mathrm{mg} /$ pot, $\mathrm{J}_{2}=$ Second stage juvenile of Meloidogyne incognita, $\mathrm{Th}=$ Trichoderma harzianum, $\mathrm{Pc}=$ Pochonia chlamydosporia

All the treatments were replicated five times. The plants were watered regularly and pots were arranged in a completely randomized design. The plants were harvested after 60 days of sowing. After harvesting plant-growth parameter such as, plant height, leaf area, number of pods, number of seeds, seed weight and number of galls were statistically analyzed.

Biochemical tests were performed 15 days after nematode inoculation. The leaf protein content was estimated by the method of Lowry et al., [22] (Figure 1I). The chlorophyll content in fresh leaves was estimated by the method described by Arnon [23]. Nitrogen and phosphorus contents in the leaves were estimated by the method of Linder [24] and Fiske and Subbarow [25], respectively. Nitrate reductase activity (NRA) was measured by adopting the methodology of Jaworski [26].
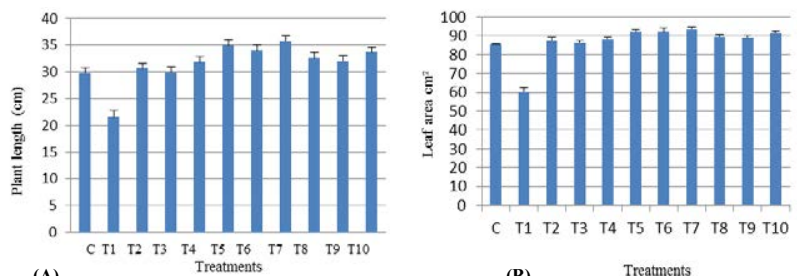

(A)

(B)

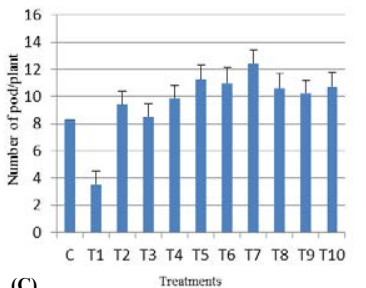

(C)
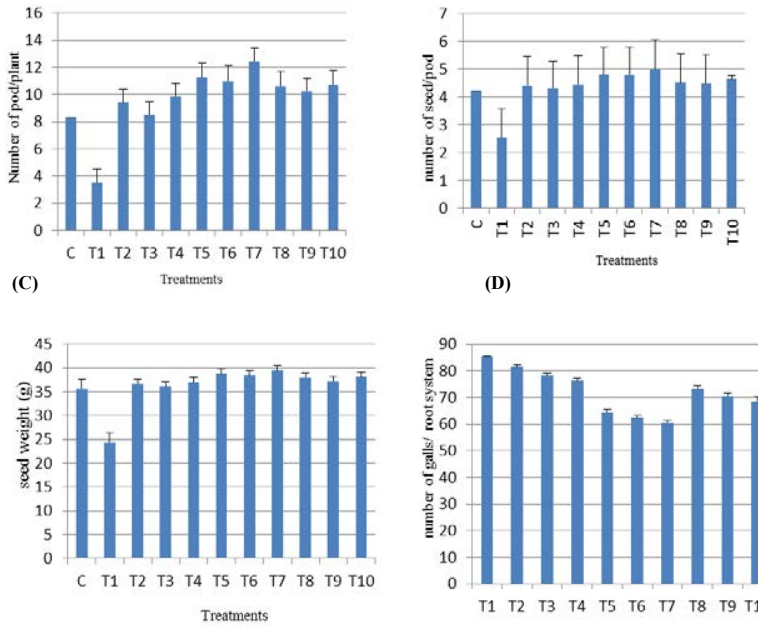

(D)
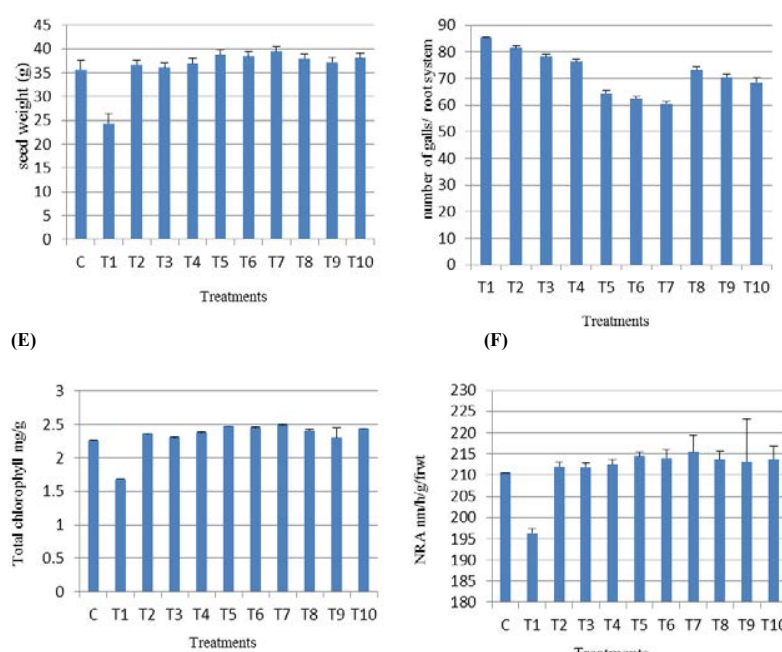

(G)

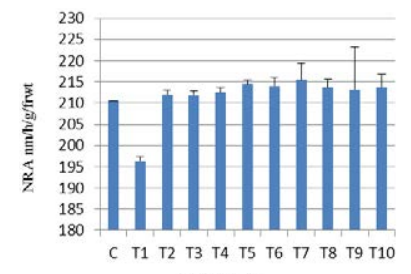

(H)

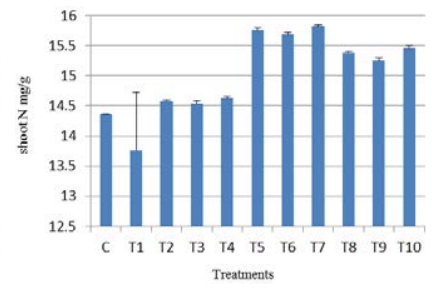

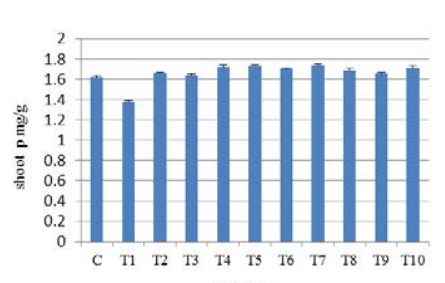

(K)

Figure 1: Figures represent the combined effect of Potassium fertilizer along with $T$. harzianum and $P$. chlamydosporia on plant length (A), Leaf area $(B)$, number of pods/plant $(C)$, number of seed/pod (D), seed weight $(E)$, number of galls/root system $(F)$, total chlorophyll content $(G)$, NRA content $(\mathrm{H})$, Leaves protein content $(\mathrm{I})$, Shoot $\mathrm{N}$ content $(\mathrm{J})$ and Shoot $\mathrm{P}$ content $(\mathrm{K})$, of $M$. incognita infested $P$. vulgaris, and error bars represent the mean $\pm \mathrm{SD}$ of replicates. 


\section{Statistical analysis}

Data was analyzed by one-way analysis of variance and Least Significant Difference was calculated at $\mathrm{P}=0.05$ to test for significance. The analysis was performed with the software R ( $\mathrm{R}$ Development Core Team, 2011).

\section{Result and Discussion}

Data presented in the (Table 1), revealed that combined application of Trichoderma harzianum, Pochonia chlamydosporia and potassium (K2) significantly $(\mathrm{P}=0.05)$ increased plant height in all the treatments except (T1), over the control (C). Highest increase in plant length (Figure 1A) was recorded in T7 $(35.83 \mathrm{~cm})$ as compared to uninocultaed control, due to sufficient dose of $\mathrm{K} 2$ and both biofertilizers, which had given best response in comparison to other two doses of potassium. Combined application of NPK fertilizer and biofertilizers and organic manure increased the root length of $B$. campestris [27]. Trichoderma improved nitrogen fixation improved absorption efficiency of solubilized micronutrients such as $\mathrm{Fe}, \mathrm{Mn}$, and $\mathrm{Cu}$ etc. and improved the plant growth [10].

Melakebarhan et al., (1988) reported that physiological and growth response of $M$. incognita infected bean (Phaseolus vulgaris) can be improved by applying $\mathrm{KNO}_{3}$ to the soil. Long term application of organic manure and biofertilizers were reported to increase the soil nutrients such as organic carbon, nitrogen, phosphorus, potassium and also soil health $[28,29]$. Significant $(\mathrm{P}=0.05)$ increase in the leaf area was observed in all the treatments except $\mathrm{T} 2$ and $\mathrm{T} 3$, where non-significant increases were encountered (87.38, $86.56 \mathrm{~cm}^{2}$ respectively) (Figure $\left.1 \mathrm{~B}\right)$. Maximum increase was observed in T7 $\left(93.56 \mathrm{~cm}^{2}\right)$ over the control plants. In nematode inoculated plants (T1), significant reduction at $(\mathrm{P}=0.05)$ was recorded $\left(60.28 \mathrm{~cm}^{2}\right)$, when compared with the control. Foliar application of $\mathrm{K}_{2} \mathrm{PO}_{3}$ positively affected parameters of cowpea, grown under salinity stress conditions such as plant height, number of green leaves per plant and both fresh and dry weight [30]. Mineral fertilizers such as ammonium nitrate, potassium nitrate, potassium sulphate, superphosphate and triple phosphate reduced the population of $M$. javanica [31]. Number of pods per plant and number of seeds per pod decreased significantly $(3.50,2.54)$ respectively, in nematode inoculated plant (T1), when compared with the control. However, maximum increase was observed in $\mathrm{T} 7(12.41,5.00)$ respectively on comparing with un-inoculated control (Figure 1D). T1 plants exhibited significant $(\mathrm{P}=0.05)$ decrease in seed weight $(24.37)$ whereas significant increases $(\mathrm{P}=0.05)$ were recorded in $\mathrm{T} 5, \mathrm{~T} 6, \mathrm{~T} 7, \mathrm{~T} 8, \mathrm{~T} 10$ (Figure 1E). However, the non-significant increase was observed in T2, T3, T4, and
T9 plant over the control. Sa et al., [32] reported significant difference in the number of pods per plant in French bean after application of different doses of various fertilizers. A number of researchers have recorded increase in potato tubers yield as a result of the increasing level of potassium $(\mathrm{K})$ fertilization [33,34]. Weir [35] suggested that application of foliar potassium on cotton plant, at the beginning of two weeks after first bloom, increased in the lint yield but later applications in the season had little response.

The number of galls was reduced significantly at Probability $=0.05$ level in all the treatment, while the maximum reduction was observed in T7 (60.34), over the control (Figure 1F). It was also observed that $P$. chlamydosporia along with K2 further reduced number of galls than T. harzianum due to its nematicidal activity, however, the combined application of both biofertilizers and potassium fertilizers (K2) give the better response in controlling the nematode. The increase in the plant growth may be ascribed to increase the nutrient availability and the reduction of nematode population might be due to toxic compound. Applications of potash in combination with phosphorus or nitrogen or potash alone check the reniform nematode multiplication on okra to a great extent [36]. Omaima et al., (2012) reported that application of $\mathrm{K}_{2} \mathrm{O}$ along with Bio-Nematon enhanced the plant growth, yield and improved the plant defense against fungal root rot and $M$. incognita infection.

Total chlorophyll content in leaves was reduced significantly (1.68 $\mathrm{mg} / \mathrm{g}$ ) in $\mathrm{T} 1$, and maximum chlorophyll content was observed in T7 $(2.49 \mathrm{mg} / \mathrm{g}$ ) treated with both fungal biocontrol agents (T. harzianum and $P$. chlamydosporia) along with potassium at the time of nematode inoculation, over the control (Table 2) (Figure 1G). El-Brammy et al., [37] reported that application of potassium in soil and as a foliar spray increased the plant height, number of branches, leaf chlorophyll number of pods/plant, 100 grain weight $(\mathrm{g})$ and grain yield of faba bean plant infected with chocolate spot and rust disease. Barber et al., [38] found that chlorophyll content of cotton plants decreased under the potassium deficiency leading to marked reduction in the rate of photosynthesis close to $95 \%$ (Figure 1C). Nitrate reductase activity and protein content were significantly lower $(196.35 \mathrm{~nm} / \mathrm{h} / \mathrm{g} / \mathrm{frwt}, 3.28 \%$ respectively) in $\mathrm{T} 1$, in which the plants were inoculated with $1,000 \mathrm{~J}$ of $M$. incognita alone without fungal biocontrol agents and potassium fertilizer in comparison to control. However, the maximum increases in NRA and protein content were recorded in T7 plants $(215.50 \mathrm{~nm} / \mathrm{h} / \mathrm{g} /$ frwt, $3.65 \%$, respectively) (Figure $1 \mathrm{H}$ ), where the plants were treated with potassium (K2) along with both fungal biocontrol agents at the time of nematode inoculation as compared to the control (Table-2).

\begin{tabular}{|c|c|c|c|c|c|c|}
\hline Treatments & Plant length $\mathbf{( c m )}$ & Leaf area $\mathbf{( c m}^{\mathbf{2}} \mathbf{)}$ & $\begin{array}{c}\text { Number of pods/ } \\
\text { plant }\end{array}$ & Number of seed/pod & 100 seed weight (g) & Number of galls/root system \\
\hline C & 29.88 & 85.57 & 8.30 & 4.23 & 35.61 & 0 \\
\hline T1 & 21.58 & 60.28 & 3.50 & 2.54 & 24.37 & 85.34 \\
\hline T2 & 30.65 & 87.38 & 9.41 & 4.42 & 36.66 & 81.35 \\
\hline T3 & 30.00 & 86.56 & 8.52 & 4.33 & 36.12 & 78.20 \\
\hline T4 & 31.75 & 88.34 & 9.87 & 4.45 & 37.00 & 76.34 \\
\hline T5 & 34.94 & 92.34 & 11.29 & 4.80 & 38.74 & 64.56 \\
\hline T6 & 34.00 & 92.00 & 11.00 & 4.78 & 38.42 & 62.44 \\
\hline T7 & 35.83 & 93.56 & 12.41 & 5.00 & 39.48 & \\
\hline T8 & 32.58 & 89.55 & 10.64 & 4.52 & 37.92 & \\
\hline T9 & 32.00 & 89.00 & 10.25 & 4.50 & 37.20 & 73.41 \\
\hline T10 & 33.68 & 91.32 & 10.75 & 4.65 & 38.00 & 70.59 \\
\hline LSD=0.05 & 1.73 & 2.31 & 1.70 & 1.56 & 2.07 & 68.37 \\
\hline
\end{tabular}

Table 1: Combined effect of biofertilizers ( T. harzianum, $P$. chlamydosporia) and different doses of Potassium on the growth of Phaseolus vulgaris infested with M. incognita. 


\begin{tabular}{|c|c|c|c|c|c|}
\hline Treatments & $\begin{array}{c}\text { Total } \\
\text { chlorophyll } \\
\mathbf{m g} / \mathbf{g}\end{array}$ & $\begin{array}{c}\text { NRA nm/ } \\
\text { h/g fr wt }\end{array}$ & $\begin{array}{c}\text { Leaves } \\
\text { protein\% }\end{array}$ & $\begin{array}{c}\text { Shoot N } \\
\mathbf{m g} / \mathbf{g}\end{array}$ & $\begin{array}{c}\text { Shoot P } \\
\mathbf{m g} / \mathbf{g}\end{array}$ \\
\hline C & 2.25 & 210.54 & 3.35 & 143.6 & 1.62 \\
\hline T1 & 1.68 & 196.35 & 3.28 & 13.76 & 1.38 \\
\hline T2 & 2.35 & 212.00 & 3.40 & 14.58 & 1.66 \\
\hline T3 & 2.30 & 211.85 & 3.38 & 14.54 & 1.64 \\
\hline T4 & 2.38 & 212.50 & 3.49 & 14.62 & 1.72 \\
\hline T5 & 2.47 & 214.90 & 3.60 & 15.76 & 1.73 \\
\hline T6 & 2.45 & 214.00 & 3.58 & 15.68 & 1.70 \\
\hline T7 & 2.49 & 215.50 & 3.65 & 15.82 & 1.74 \\
\hline T8 & 2.41 & 213.68 & 3.54 & 15.38 & 1.69 \\
\hline T9 & 2.30 & 213.20 & 3.52 & 15.25 & 1.65 \\
\hline T10 & 2.43 & 213.75 & 3.56 & 15.45 & 1.71 \\
\hline LSD=0.05 & 0.03 & 6.19 & 0.06 & 0.49 & 0.02 \\
\hline
\end{tabular}

Table 2: Combined effect of biofertilizers ( $T$. harzianum, $P$. chlamydosporia) and different doses of Potassium on the biochemical parameters of Phaseolus vulgaris infested with $M$. incognita.

The shoot $\mathrm{N}$ and $\mathrm{P}$ content was reduced significantly in $\mathrm{T} 1$ (13.76 $\mathrm{mg} / \mathrm{g}$ and $1.38 \mathrm{mg} / \mathrm{g}$, respectively) in comparison to control. However, the treatment $\mathrm{T} 7$ exhibited the maximum increased in shoot $\mathrm{N}$ and $\mathrm{P}$ content over the control (Table 2) (Figure 1J and 1K).

Application of potassium along with P. chlamydosporia for controlling root-knot nematode was not reported earlier. From the present study it was evident that of $P$. chlamydosporia with potassium were compatible in controlling the nematode. Potassium plays an important role in enzyme activation involved in ATP production, in regulation of photosynthetic rate that improves the plant growth and yield [39]. Potassium is associated with disease reduction, it provide resistance to the plant by suppressing the disease caused by the pathogen. Increased level of Potassium showed the $80 \%$ reduction in root-knot nematode population in tomato plants [20].

Fungal biocontrol agents which we were used in our experiment having the nematicidal activity, they parasitized the egg, larvae of the root-knot nematode and reduced the nematode population. The findings from the experiments clearly showed the increased plant growth parameters with decreased nematode infestation. Nematophagous fungi may increase plant growth by participation in nutrient uptake or by modification of plant growth regulators (hormones or related compounds). Improvements in uptake of nutrients and growth due to application of Trichoderma were also noticed [40-42]. T. harzianum has strong capacity to mobilizes and take up of soil nutrients [39]. Up take of $\mathrm{K}$ was found to be higher than $\mathrm{N}$ and $\mathrm{P}$ in sugarcane as also reported by Shukla et al. [42]. Trichoderma strains colonise the plant roots, establishing chemical communication and systemically altering the expression of numerous plant genes that alter plant physiology and may result in the improvement of abiotic stress resistance, nitrogen fertilizer uptake, and resistance to pathogens and photosynthetic efficiency. Application of $P$. chalymydodporia successfully established in tested plants, and suppressed the nematode growth, resulted in growth enhancement on the application with Trichoderma or alone. Attraction of the fungus Pochonia to a richer source of energy (e.g. carbohydrates) such as plant rhizo deposits may support the hypothesis that nutrition is one of the factors involved in switching from saprophytic to parasitic behavior and the fungi $P$. chlamydosporia should translocate nutrients across the mycelial network. According to Kerry [43] root exudates from tomato infected by root-knot nematodes contain more water soluble and several metal ions which support more colonization of $P$. chlamydosporia than healthy roots. It has been noted that maize supports a higher degree of fungal growth, even in the presence of high nematode populations compared to tomato (Bourne and Kerry) [41].

From our previous findings it had been suggested that Trichoderma viride and Pochonia chlamydosporia along with urea as a nitrogen fertilizer improved the plant growth of red kidney bean infested with M. incognita (Sharf et al.,) [42]. Biofertilizers (T. harzianum, $P$. chlamydosporia) along with $\mathrm{K} 2$ gave better response in controlling the nematode and also improved the plant growth and yield of Phaseolus vulgaris [43-50]. Our results suggested that application of potassium along with Trichoderma harzianum and P. chlamydosporia improved the plant growth, by increasing plant nutrient uptake properties and reducing the nematode population by their nematicidal acitivity [51].

\section{References}

1. Ehlers JD, Ferry RL, Hall AE (2002) Cowpea breeding in the USA new varieties and improved germplasm. In: Fatokun CA, Tarawali SA, Singh BB, Kormawa KM, Tamo M (eds) Challenges and Opportunities for Enchancing Sustainable Cowpea. IITA, Ibadan, Nigeria, pp. 62-77.

2. Fassuliotis G (1979) Plant breeding for root-knot nematode resistance. In Lamberti $F$ (ed) Root-knot nematode (Meloidogyne species), Systematics, Biology and Control. Taylor London: Academic Press; pp. 425-453.

3. Wyatt JE, Fassuliotis G, Johnson AW (1980) Efficacy of resistance to root-knot nematodes in snap beans. J Am So Hort Sci 105: 923-926.

4. Melakeberhan H, Brooke RC, Webster JM, D'Auria JM (1985) The influence of Meloidogyne incognita on growth, nutrient content and physiology of Phaseolus vulgaris. Physiol Plant Pathol 26: 259-268.

5. Generalao LC, Davide RG, (1995) Evaluation of biological control efficiency of three fungi grown in different substrates against Radopholus similis on banana. Biocontrol 1: 35-43.

6. Esnard JN, Mendoza NM, Zuckerman BM (1998) Effects of three microbia broth cultures and an organic amendment on growth and populations of free living and plant-parasitic nematodes on banana. Eur J Plant Pathol, 104: 457 463.

7. Butt TM, Jackson C, Magan N (2001) Introduction- fungal biological contro agents: progress, problems and potential. In: Butt TM, Jackson C, Magan N (eds) Fungi as Biocontrol Agents: Progress, Problems and Potential. CAB International, Wallingford, UK, pp. 1-8.

8. Liu T, Wang L, Duan YX, Chen LJ, Wang X (2007) Effects of Trichoderma viride on egg hatching and juvenile mortality of Meloidogyne halpa. Acta Agriculturae Universitatis Jiangxiensis (Natural Sciences Edition) 4: 566-569.

9. Sharon E, Bar-Eyal M, Chet I, Herrera-Estrella A, Kleifeld O, et al. (2001) Biological Control of the Root-Knot Nematode Meloidogyne javanica by Trichoderma harzianum. Phytopathology 91: 687-693.

10. Altomare C, Norvell WA, Bjorkman T, Harman GE (1999) Solubilization of phosphates and micronutrients by the plant-growth-promoting and biocontrol fungus trichoderma harzianum rifai 1295-22 Appl Environ Microbiol 65: 29262933.

11. Kerry BR, Hidalgo-Diaz L (2004) Application of Pochonia chlamydosporia in the integrated control of root-knot nematode on originally grown vegetables crop in Cuba. Multitropic Interaction in Soil and Integrated control. ROBC-WPRC Bull 27: 123-126.

12. Bordallo JJ, Lopez-Llorca LV, Jansson HB, Salinas J, Persmark L, et al. (2002) Effects of egg-parasitic and nematode-trapping fungi on plant roots. New Phytologist 154: 491-499.

13. Maciá-Vicente JG, Jansson HB, Talbot NJ, Lopez-Llorca LV (2009) Real-time PCR quantification and live-cell imaging of endophytic colonization of barley (Hordeum vulgare) roots by Fusarium equiseti and Pochonia chlamydosporia. New Phytol 182: 213-228.

14. Monfort E, Lopez-Llorca LV, Jansson HB, Salinas J, Park JO, et al. (2005) Colonization of seminal roots of wheat and barley by egg-parasitic nematophagous fungi and their effects on Gaeumannomyces graminis var. tritici and development of root rot. Soil Biol Biochem 37: 1229-1235

15. Mácia-Vicente JG, Rosso LC, Ciancio A, Janson HB, Lopez-Llorca LV (2009) Colonization of barley roots by endophytic Fusarium equiseti and Pochonia 
Citation: Sharf R, Hisamuddin, Abbasi, Akhtar A (2014) Management of Root-Knot Disease in Phaseolus vulgaris Using Potassium Fertilizer and Biocontrol Agents. J Plant Pathol Microb 5: 242. doi:10.4172/2157-7471.1000242

chlamydosporia: effects on plant growth and disease. Annals of Applied Biology 155: 391-401.

16. Melakeberhan H, Webster JM, Brooke RC, D'Auria JM, Cackette M (1987) Effect of Meloidogyne incognita on Plant Nutrient Concentration and Its Influence on the Physiology of Beans. J Nematol 19: 324-330.

17. Shamel, Rostami MT (1997) Effect of different 18 potassium fertilizer on quantity and quality yield of flue-cured tobacco. Tirtash Tobacco Research Institute Publishers, Mazandaran, Iran. Code Number, 2-101-79.

18. Krauss A, (1999) Balanced Nutrition and Biotic Stress. IFA Agric Conf on Managing Plant Nutrit, 29 June-2 July 1999, Barcelona, Spain.

19. Prabhu AS, Fageria NK, Hular DM, Rodriahues FA (2007) Potassium and plan disease In: Datnoff IE Elmer WH, Tuber, DM (edn) Mineral nutrition and plant disease. APS Press, St. Paul, pp: 57-78

20. Gupta DC, Mukhopadhayaya MC (1971) Effect of N, P and K on the root-knot nematode M. javanica (Treub) Chitwood Sci Cult 37: 246-247.

21. Riker AJ, Riker AS (1936) In: Introduction to Research on Plant Diseases. John S. Swift and Co. Inc., St. Louis, Chicago.

22. Lowry OH, Rosebrough NJ, Farr AL, Randall RJ (1951) Protein measurement with the Folin phenol reagent. J Biol Chem 193: 265-275.

23. Arnon DI (1949) Copper enzymes in isolated chloroplasts. Polyphenoloxidase in Beta vulgaris. Plant Physiol 24: 1-15.

24. Lindner RC (1944) Rapid analytical methods for some of the more common inorganic constituents of plant tissues. Plant Physiol 19: 76-89.

25. Fiske HC, Subbarow $Y$ (1925) The colorimetric determination of phosphorus. $J$ Biol Chem 66: 375-400

26. Jaworski EG (1971) Nitrate reductase assay in intact plant tissues. Biochem Biophys Res Commun 43: 1274-1279.

27. Datta JK, Banerjee A, Sikdar MS, Gupta S, Mondal NK (2009) Impact of combined exposure of chemical fertilizer, biofertilizers and compost on growth, physiology and productivity of Brassica campestris in old alluvial soil. Journal of Environmental Biology 30: 797-800.

28. Bhunia SR, Chauhan BS, Yadav BS, Bhati AS (2006) Effect of phosphorus, irrigation and Rhizobium on productivity, water use and nutrient uptake in fenugreek (Trigonella foenum-graecum). Indian J Agron 51: 239-241.

29. Kumar S, Singh D, Nepalia V (2009) Performance of fenugreek (Trigonella foenum-graecum) varities at various fertilizer levels and bio fertilizer inoculations. Indian J Agr Res 79: 80-83

30. Hussain MM, Shaaban MM, A.K.M El- Sandy, (2008) Response of cowpea plants grown under salinity stress to PK-foliar applications. Am J Plant Physiol. 3: $81-88$

31. Mareg MF, Salem FM, Ebieda AM (2000) Effect of certain organic and inorganic soil amendments on Meloidogyne javanica in sandy soil. Egypt J Agro Nematol 4: 83-94

32. Sa ME, De Buzetti S, Morello S, Deziderio (1982) Effect of plant density and phosphate fertilizer on bean production. Centro Nacional de Pesquisa Arroz Feijao, pp: 101-103.

33. El- Gamal AM, (1985) Effect of potassium level on yield and quality. J Agric Sc Mansoura Univ., 10: 1473-1476

34. Humadi FM, (1986) Influence of potassium rates on growth and yield of potato (Solanum tuberosum). Iraq J Agric Sci (Zanco) 4: 69-76

35. Weir B (1988) Foliar potassium bumps cotton yields. California research reports consistent yield increase to foliar applied potassium over a period of year in the San Joaquin Valley Fluid J, 6: 10-13.
36. Sivakumar CV, Meerazainuddin M (1974) Influence of N, P and K on the Ren form nematode, Rotylenchulus reniformis and its effect on the yield of okra. Indian J Nematol 4: 243-244.

37. El-Bramaway MASA, Shaban WI (2010) Effect of potassium fertilization on agronomic characters and resistance to chocolate spot and rust disease in faba bean. Tunisian Journal of Plant Protection 5: 131-150

38. Barber SA, Munson RD, Dancy WB (1985) In: Production, Marketing and Use of Potassium Fertilizers. 3rd edn Engelstad, Madison, USA, 537 pp.

39. Benitez T, Rincon AM, Limon MC, Codon AC (2004) Biocontrol mechanisms of Trichoderma strains. Int. Microbiol. 7: 249-260.

40. Srivastava SN, Singh V, Awasthi SK (2006) Trichoderma induced improvement in growth, yield and quality of sugarcane. Sugar Tech 8: 166-169.

41. Bourne JM, Kerry BR (1999) Effect of the host plant on the efficacy of Verticillium as a biological control agent of root-knot nematoes at different nematode densities and fungal application rates. Soil Biology and Biochemistry, 31: 7584.

42. Sharf R, Abbasi H, Akhtar A (2014) Combined effect of biofertilizers and fertilizer in the management of Meloidogyne incognita and also on the growth of red kidney bean (Phaseolus vulgaris). Int J plant Pathol 5: 1-11.

43. Shukla SK, Yadav RL, Suman A, Singh PN (2008) Improving rhizospheric environment and sugarcane ratoon yield through bio agents amended farm yard manure in udic ustochrept soil. Soil Tillage Res. 99: 158-168.

44. Kerry BR (2000) Rhizosphere interactions and the exploitation of microbia agents for the biological control of plant-parasitic nematodes. Annu rev phytopathol 38: 423-441.

45. Melakeberhan H, Webster JM, Brook RC, D'Auria JM (1988) Effect of KNO3 on $\mathrm{CO} 2$ exchange rate, nutrient concentration and yield of Meloidogyne incognita infected bean. Revue Nematol 11: 391-397.

46. Maima Hafez M, Karima Haggag HE, Waffa El-Nagdi MA, El-Shamma MS (2012) Effect of potassium fertilizers and Bio-Nematon on performance of Williams Banana Cv. For Controlling Fungi rot and nematode root knot diseases. Journal of Applied Sciences Research 8: 646-657

47. Dean CB, Nielsen JD (2007) Generalized linear mixed models: a review and some extensions. Lifetime Data Anal 13: 497-512.

48. Simpson K (1986) In: Fertilizers and Manures. 3rd Longman group limited, Harlow, UK, pp: 209

49. Valentine IK, Kalevitch MV, Borsari B (2003) Phenolic cycle in plants and environment. J Cell and Molecular Biol, 2: 13-18.

50. Yadav RL, Singh V, Srivastav SN, Lal RJ, Sangeeta S, et al. (2008) Use of Trichoderma harzianum for the control of red rot disease of sugarcane. Sugarcane Int. (UK) 26: 28-33

51. Zekari M, Obreza TA (2009) Plant nutrients for citrus trees. SL, 200, UF/IFAS Extension service, Institute of Food and Agricultural Sciences, University of Florida. 